\title{
Different corrinoid specificities for cell growth and the cobalamin uptake system in Euglena gracilis $\mathbf{z}$
}

\author{
Fumio Watanabe, ${ }^{1 *}$ Yoshinisa NaKano ${ }^{2}$ and ERhard StupPerich ${ }^{3}$ \\ ${ }^{1}$ Laboratory of Nutrition and Food Science, Hagoromo-gakuen College, 1-89-1 Hamadera-minamimachi, Sakai, \\ Osaka 592, Japan \\ ${ }^{2}$ Department of Agricultural Chemistry, University of Osaka Prefecture, Sakai, Osaka 591, Japan \\ ${ }^{3}$ Abteilung Angewandte Microbiologie, Universitat Ulm, Albert-Einstein-Allee 11, D-7900 Ulm, Germany
}

(Received 6 February 1992; revised 15 May 1992; accepted 8 June 1992)

\begin{abstract}
A variety of cobalamin analogues synthesized chemically or microbiologically were used to study the corrinoid specificities of cell growth and the cobalamin uptake system in Euglena gracilis z. Although Euglena could not utilize most of the analogues for cell growth, benzimidazolyl cobamide, cyanocobalamin- $O^{5}$-phosphate, and cyanocobalamin- $b-,-d$ - and $e$-monocarboxylates had effects similar to that of cyanocobalamin on cell growth. It is suggested that Euglena cells have the ability to synthesize 'complete cobalamin' from the acid derivatives (amidation reaction) and/or the phosphate derivative (dephosphorylation reaction). Inhibition of uptake of radiolabelled cyanocobalamin caused by addition of various analogues indicates that both the $\alpha$-lower axial ligand (the cobalt-coordinated nucleotide) and the (b)-propionamide side-chain of the cobalamin molecule are essential for the cobalamin uptake system in Euglena. These results indicate that there are different corrinoid specificities for cell growth and the cobalamin uptake system in $E$. gracilis $\mathbf{z}$.
\end{abstract}

\section{Introduction}

Euglena gracilis z, a photosynthesizing unicellular protozoan, has characteristics of both animal and plant cells (Wolken, 1967). Euglena cells require cobalamin (Cbl) for growth and have the ability to take up and accumulate exogenous Cbl (Ross, 1952; Varma et al., 1961). The kinetics of $\mathrm{Cbl}$ uptake in Euglena are biphasic, as in Escherichia coli (DiGirolamo \& Bradbeer, 1971; Bradbeer \& Woodrow, 1976) and the protozoan Ochromonas malhamensis (Bradbeer, 1971). Euglena pellicle (a cell-membrane complex) fragments isolated by sucrose density-gradient centrifugation contain $\mathrm{Cbl}-$ binding proteins which are involved in the $\mathrm{Cbl}$ uptake system (Watanabe et al., 1988a).

In addition to Cbl-dependent enzymes (methionine synthase, methylmalonyl-CoA mutase and ribonucleotide reductase), $E$. gracilis z contains numerous non-enzymic Cbl-binding proteins, which are distributed in the cytosolic, mitochondrial, chloroplastic and microsomal fractions (Isegawa et al., 1984). Some of these Cblbinding proteins have been purified and characterized

* Author for correspondence. Tel. 722657000 ; fax 722657005 .

Abbreviation: Cbl, cobalamin.
(Watanabe et al., 1987a, $b ; 1988 a, b$ ). Thus, Euglena cells have unique intracellular $\mathrm{Cbl}$ transfer and/or accumulation system(s), which differ from both mammalian and bacterial systems (Watanabe \& Nakano, 1991).

In this study, we demonstrate the corrinoid specificities of Euglena cell growth and the Cbl uptake system, and discuss why there are differences between the two in this organism.

\section{Methods}

Organism and culture. Euglena gracilis $\mathrm{z}$ was normally cultured for $5 \mathrm{~d}$ at $27^{\circ} \mathrm{C}$ with illumination $\left(50 \mu \mathrm{E} \mathrm{m}^{-2} \mathrm{~s}^{-1}\right)$ in Koren-Hutner medium (CN-Cbl, $5 \mu \mathrm{g}$ per litre of medium) (Koren \& Hutner, 1967). For Cbl uptake experiments and $\mathrm{Cbl}$ analogue-feeding experiments, we used Euglena cells grown in Cbl-limited medium A (33.3 $\left.\mathrm{ng} \mathrm{1}^{-1}\right)$ or medium B $\left(0.22 \mathrm{ng} \mathrm{l}^{-1}\right)$, to reduce their cellular $\mathrm{Cbl}$ contents.

Corrinoid compounds (see Table 1). $\mathrm{CN}-\mathrm{Cbl}, \mathrm{OH}-\mathrm{Cbl}, \mathrm{CH}_{3}-\mathrm{Cbl}$ AdoCbl and (CN)CN-Cbi were obtained from Sigma. [G- $\left.{ }^{3} \mathrm{H}\right] \mathrm{CN}-\mathrm{Cbl}$ $\left[9 \cdot 2 \mathrm{Ci} \mathrm{mmol}^{-1}\left(340 \mathrm{GBq} \mathrm{mmol}{ }^{-1}\right)\right]$ was obtained from Du Pont-NEN. (2-AMP)CN-Cbl was kindly provided by Dr T. Kamikubo (Kobe Women's University, Japan)

(Bza)CN-Cba, (5-OH-Bza)CN-Cba, (Ade)CN-Cba and ( $p$-Cre)CNCba were prepared microbiologically and purified as described previously (Stupperich et al., 1986, 1988, 1990; Stupperich \& Krautler, 1988). 
$\mathrm{CN}-\mathrm{Cbl}(b-\mathrm{OH}), \mathrm{CN}-\mathrm{Cbl}(d-\mathrm{OH})$ and $\mathrm{CN}-\mathrm{Cbl}(e-\mathrm{OH})$ were prepared as described by Yamada \& Hogenkamp (1972) and Toraya et al. (1979). The $\mathrm{CN}-\mathrm{Cbl}(b-\mathrm{OH}),(d-\mathrm{OH})$ and $(e-\mathrm{OH})$, which were prepared and designated, have been reported to be $\mathrm{CN}-\mathrm{Cbl}(d-\mathrm{OH}),(e-\mathrm{OH})$ and ( $b-\mathrm{OH}$ ), respectively, as determined by ${ }^{13} \mathrm{C}-\mathrm{NMR}$ analysis (Anton $e t$ al., 1980). The revised designations of the acid derivatives were used in the experiments described in this paper. CN-Cbl(13-epi) (Bonnett et al., 1971 a), CN-Cbl(c-lactam) (Bonnett et al., 1957) and CNCbl(5'-O-P) (Friedmann, 1971) were prepared by the methods described in the references cited. $\mathrm{CN}-\mathrm{Cbl}\left(5^{\prime}-O-\mathrm{Suc}\right)$ and $\mathrm{CN}-\mathrm{Cbl}\left[2^{\prime}-\right.$ $\left.O, 5^{\prime}-O-(\mathrm{Suc})_{2}\right]$ were prepared as described by Toraya et al. $(1975 a)$.

Each of the CN-Cbl derivatives was further purified by HPLC using a Shimadzu HPLC apparatus (LC-7A pump, SPD-7AV spectrophotometer) and a Hitachi chromato-data processor (D-2500). The sample was put on a reversed-phase HPLC column (Wakosil 5C18-200; $4.6 \times 150 \mathrm{~mm}$ ) and isocratically eluted with water/methanol/acetic acid $\left(79: 20: 1\right.$, by vol.) at a flow rate of $1.0 \mathrm{ml} \mathrm{min}^{-1}$. Corrinoids were monitored by measuring the absorbance at $361 \mathrm{~nm}$. Each of the $\mathrm{CN}-\mathrm{Cbl}$ derivatives gave a single peak in HPLC. The purity of the $\mathrm{Cbl}$ analogues was further checked as follows. $\mathrm{CN}-\mathrm{Cbl}(b-\mathrm{OH}),(d-\mathrm{OH})$ and $(e-\mathrm{OH})$ were checked by TLC on precoated silica gel plates with 2-butanol/acetic acid/water (127:1:50, by vol.) or 2-propanol/ $\mathrm{NH}_{4} \mathrm{OH} /$ water $(7: 1: 2$, by vol.) as the solvent (Toraya et al., 1979). $\mathrm{CN}-\mathrm{Cbl}(13-\mathrm{epi})$ was characterized by paper chromatography with 1-butanol/ethanol/water ( $50: 15: 35$, by vol.) or 1-butanol/2-propanol/ water (37:36:37, by vol.) as the solvent (Tkachuck et al., 1974). $\mathrm{CN}$-Cbl(c-lactam) was checked by paper chromatography with 2-butanol containing aqueous ammonia solution as the solvent (Bonnett et al., 1957). The phosphate derivative was checked by TLC on silica gel with 2 -butanol/acetic acid/water $(127: 1: 50$, by vol.) or 1-butanol/2-propanol/water (10:7:10, by vol.) (Renz, 1971). The succinate derivatives were checked by paper chromatography with 2-butanol/water/acetic acid $(70: 30: 1$, by vol.) (Toraya et al., 1975a).

The concentrations of the $\mathrm{Cbl}$ analogues prepared chemically were determined spectrophotometrically as follows. The concentrations of $\mathrm{CN}-\mathrm{Cbl}(b-\mathrm{OH}), \mathrm{CN}-\mathrm{Cbl}(d-\mathrm{OH}), \mathrm{CN}-\mathrm{Cbl}(e-\mathrm{OH}), \mathrm{CN}-\mathrm{Cbl}\left(5^{\prime}-O-\mathrm{P}\right)$, $\mathrm{CN}-\mathrm{Cbl}\left(5^{\prime}-\mathrm{O}-\mathrm{Suc}\right)$ and $\left.\mathrm{CN}-\mathrm{Cbl}\left[2^{\prime}-O, 5^{\prime}-\mathrm{O} \text {-(Suc) }\right)_{2}\right]$ were determined on the basis of $\varepsilon_{361}=28.06 \times 10^{3} \mathrm{M}^{-1} \mathrm{~cm}^{-1}$ for $\mathrm{CN}-\mathrm{Cbl}$ (Friedrich, 1964). That of $\mathrm{CN}-\mathrm{Cbl}(13-e p i)$ was done on the basis of $\varepsilon_{367}=$ $20 \cdot 6 \times 10^{3} \mathrm{M}^{-1} \mathrm{~cm}^{-1}$ for (CN)CN-Cbl(13-epi) (Bonnett et al., 1971 b). That of $\mathrm{CN}-\mathrm{Cbl}\left(c\right.$-lactam) was done on the basis of $\varepsilon_{359}=$ $22.4 \times 10^{3} \mathrm{M}^{-1} \mathrm{~cm}^{-1}$ (Bonnett et al., 1957).

Cbl analogue-feeding experiments. Each of the $\mathrm{Cbl}$ analogues $(5 \mu \mathrm{g} \mathrm{per}$ litre of medium) was added aseptically to a culture $(50 \mathrm{ml})$ of Euglena cells (about $0.5 \times 10^{6} \mathrm{cells} \mathrm{ml}^{-1}$ ) which had been grown for $5 \mathrm{~d}$ in the $\mathrm{Cbl}$-limited medium B. Cells that had been fed each $\mathrm{Cbl}$ analogue were further cultured for $6 \mathrm{~d}$ under the same conditions. A sample $(1.0 \mathrm{ml})$ of culture was taken every $24 \mathrm{~h}$ after addition of the $\mathrm{Cbl}$ analogue and cell numbers were counted in a haemocytometer.

Assay of $\mathrm{Cbl}$ uptake activity in living cells of Euglena. Euglena cells (about $10^{7}$ cells per $\mathrm{ml}$ of medium) grown for $5 \mathrm{~d}$ in $50 \mathrm{ml}$ of the Cbllimited medium A were collected aseptically by centrifugation at $2000 \mathrm{~g}$ for $5 \mathrm{~min}$, washed with glutamate buffer, $\mathrm{pH} 4 \cdot 0$, containing $56 \mathrm{mM}$ glucose, $18 \mathrm{mM}$-sodium glutamate, $2.6 \mathrm{mM}$-histidine $/ \mathrm{HCl}$ and $2.2 \mathrm{mM}$ $\mathrm{KH}_{2} \mathrm{PO}_{4}$, and suspended in $50 \mathrm{ml}$ of the same buffer. The suspended cells were pre-incubated with shaking at $27^{\circ} \mathrm{C}$ for $5 \mathrm{~h}$ under the same irradiance as used for growth. The assay mixture $(1.0 \mathrm{ml})$ for $\mathrm{Cbl}$ uptake activity contained $10 \mathrm{nM}-\left[\mathrm{G}-{ }^{3} \mathrm{H}\right] \mathrm{CN}-\mathrm{Cbl}$, glutamate buffer, pH 4.0, and $10^{5}$ Euglena cells. In the case of experiments to study inhibition of uptake, $100 \mathrm{~nm}$ each of the $\mathrm{Cbl}$ analogues was added to the mixture. The mixture, after incubation for $2 \mathrm{~h}$ at $4{ }^{\circ} \mathrm{C}$ (to study the initial phase or energy-independent process) or $27^{\circ} \mathrm{C}$ (to study total $\mathrm{Cbl}$ uptake $=$ energy-independent and -dependent processes) in the dark, was immediately filtered through a membrane filter (cellulose acetate type, $0.45 \mu \mathrm{m}$ pore size, $25 \mathrm{~mm}$ diameter) and washed three times with $5 \mathrm{ml} 0.9 \%(\mathrm{w} / \mathrm{v}) \mathrm{NaCl}$. The radioactivity on the dried membrane filter was counted with a liquid scintillation counter (Aloka LSC 903). The $\mathrm{Cbl}$ uptake in the secondary phase (energy-dependent process) was calculated by subtracting the radioactivity in the initial phase $\left(\right.$ at $4{ }^{\circ} \mathrm{C}$ ) from that in the initial and secondary phases (at $27^{\circ} \mathrm{C}$ ).

Corrinoid extraction and assay with HPLC. Corrinoids were extracted from cells by the $\mathrm{KCN}$-boiling method as described previously (Watanabe et al., 1991). The extract was desalted and concentrated by Amberlite XAD-4 column chromatography as described by Stupperich et al. (1986). The $80 \%$ methanol eluent was evaporated to dryness and dissolved in $500 \mu \mathrm{l}$ of water. Corrinoids in the concentrated solution were partially purified by HPLC (Wakosil 5C18-200 HPLC column) with $0.1 \%(\mathrm{v} / \mathrm{v})$ acetic acid as a mobile phase; corrinoids were eluted with $80 \%(\mathrm{v} / \mathrm{v})$ acetonitrile $/ 0 \cdot 1 \%(\mathrm{v} / \mathrm{v})$ acetic acid and monitored by measuring absorbance at $551 \mathrm{~nm}$. Corrinoid fractions were pooled, evaporated to dryness and dissolved in $200 \mu \mathrm{l}$ of water. Corrinoids in the final solution were assayed by the same HPLC system with water/ methanol/acetic acid (79:20:1, by vol.) as a mobile phase.

Materials. The Wakosil 5C18-200 HPLC column $(4.6 \times 150 \mathrm{~mm})$ was obtained from Wako Chemicals, Japan. Cellulose acetate membrane filters were obtained from Advantec, Japan. Amberlite XAD-4 was obtained from Japan Organo Co.

\section{Results}

\section{Structural formulae of $\mathrm{Cbl}$ analogues}

A variety of $\mathrm{Cbl}$ analogues was synthesized chemically or microbiologically to study the corrinoid specificities of cell growth and the $\mathrm{Cbl}$ uptake system in E. gracilis z. The structural formulae of $\mathrm{Cbl}$ and partial structures of $\mathrm{Cbl}$ analogues used in this study are shown in Fig. 1, and their abbreviations are given in Table 1.

\section{Effect of Cbl analogues on Euglena cell growth}

To clarify the corrinoid specificity of cell growth of E. gracilis z, each of the $\mathrm{Cbl}$ analogues $(5 \mu \mathrm{g}$ per litre of medium) was added aseptically to a $5 \mathrm{~d} \mathrm{Cbl}\left(0.22 \mathrm{ng} \mathrm{l}^{-1}\right)$ limited culture (containing about $0.5 \times 10^{6}$ cells ml- $^{-1}$ ). Addition of (Bza)CN-Cba or CN-Cbl(5'-O-P) increased significantly the growth of Euglena, and the culture reached a maximum density of about $20 \times 10^{6}$ cells ml $\mathrm{ml}^{-1}$ at day 6. An identical growth curve was obtained for the $\mathrm{CN}$-Cbl-supplemented culture, while in $6 \mathrm{~d}$ cultures supplemented with $\mathrm{CN}-\mathrm{Cbl}\left(5^{\prime}-\mathrm{O}-\mathrm{Suc}\right),(5-\mathrm{OH}-\mathrm{Bza}) \mathrm{CN}$ $\mathrm{Cba}$, (Ade)CN-Cba, ( $p$-Cre)CN-Cba or CN-Cbl[2'-O, 5'$O$-(Suc $)_{2}$ ] growth increased by about $47,33,30,12$ and $5 \%$, respectively, over that of the $\mathrm{CN}-\mathrm{Cbl}$-supplemented culture (Fig. $2 a, c)$. Growth in the $\mathrm{CN}-\mathrm{Cbl}(b-\mathrm{OH})$-, $\mathrm{CN}-\mathrm{Cbl}(d-\mathrm{OH})-$ and $\mathrm{CN}-\mathrm{Cbl}(e-\mathrm{OH})$-supplemented cultures increased to similar levels at day 6 as in the $\mathrm{CN}$-Cbl-supplemented culture, but the rates of cell growth in the $\mathrm{CN}$-Cbl-acid-derivative- and $\mathrm{CN}-\mathrm{Cbl}$ supplemented cultures were different during the period 
Table 1. Corrinoid compounds

\begin{tabular}{|c|c|c|}
\hline Corrinoid & Abbreviation & Structure* \\
\hline $\begin{array}{l}5 \text {-Deoxyadenosylcobalamin } \\
\text { Methylcobalamin } \\
\text { Hydroxocobalamin } \\
\text { Cyanocobalamin } \\
\text { Cyanocobalamin- } O^{s^{\prime}} \text {-phosphate } \\
\text { Cyanocobalamin- } O^{5} \text {-succinate } \\
\text { Cyanocobalamin- } O^{2}, O^{5^{\prime}} \text {-disuccinate } \\
\text { 2-Amino-2-methylpropanolyl cyanocobalamin } \\
\text { Cyanocobalamin }(c \text {-lactam) } \\
\text { Cyano-13-epicobalamin } \\
\text { Cyanocobalamin- } b \text {-monocarboxylate } \\
\text { Cyanocobalamin- } d \text {-monocarboxylate } \\
\text { Cyanocobalamin-e-monocarboxylate } \\
\text { Benzimidazolyl cobamide } \\
\text { 5-Hydroxybenzimidazolyl cobamide } \\
\text { 7-Adenyl cobamide } \\
p \text {-Cresolyl cobamide } \\
\text { Dicyanocobinamide }\end{array}$ & $\begin{array}{l}\text { AdoCbl } \\
\mathrm{CH}_{3}-\mathrm{Cbl} \\
\text { OH-Cbl } \\
\mathrm{CN}-\mathrm{Cbl} \\
\mathrm{CN}-\mathrm{Cbl}\left(5^{\prime}-O-\mathrm{P}\right) \\
\mathrm{CN}-\mathrm{Cbl}\left(5^{\prime}-O-\mathrm{Suc}\right) \\
\mathrm{CN}-\mathrm{Cbl}\left[2^{\prime}-O, 5^{\prime}-\mathrm{O}-(\mathrm{Suc})_{2}\right] \\
(2-\mathrm{AMP}) \mathrm{CN}-\mathrm{Cbl} \\
\mathrm{CN}-\mathrm{Cbl}(c \text {-lactam) } \\
\mathrm{CN}-\mathrm{Cbl}(13-\mathrm{epi}) \\
\mathrm{CN}-\mathrm{Cbl}(b-\mathrm{OH}) \\
\mathrm{CN}-\mathrm{Cbl}(d-\mathrm{OH}) \\
\mathrm{CN}-\mathrm{Cbl}(e-\mathrm{OH}) \\
\text { (Bza)CN-Cba } \\
\text { (5-OH-Bza)CN-Cba } \\
\text { (Ade)CN-Cba } \\
\text { (p-Cre)CN-Cba } \\
\text { (CN)CN-Cbi }\end{array}$ & $\begin{array}{c}1 \\
2 \\
3 \\
4 \\
5 \\
6 \\
7 \\
8 \\
9 \\
10 \\
11 \\
12 \\
13 \\
14 \\
15 \\
16 \\
17 \\
\text { Lacks the nucleotide } \\
\text { (1- } \alpha \text {-ribofuranosyl- } \\
\text { 5,6-dimethylbenzimidazol- } \\
\text { 3'-phosphate) }\end{array}$ \\
\hline
\end{tabular}

* Numbers 1-17 correspond to the structures in Fig. 1.

studied (Fig. 2b). Neither CN-Cbl(13-epi), CN-Cbl(clactam), (2-AMP)CN-Cbl nor (CN)CN-Cbi could stimulate Euglena cell growth at all (Fig. $2 b, d$ ).

\section{Intracellular form of the Cbl analogues taken up by Euglena cells}

For the $\mathrm{Cbl}$ analogues that had the same biological activity as $\mathrm{CN}-\mathrm{Cbl}$ (as shown in Fig. $2 a, b, c$ ), the intracellular form of the analogue after uptake by Euglena cells was determined by HPLC (Table 2). In the (Bza)CN-Cba-supplemented cells, most of the intracellular corrionids were recovered in the (Bza) $\mathrm{CN}-\mathrm{Cba}$ fraction, but not in $\mathrm{CN}-\mathrm{Cbl}$. While in the $\mathrm{CN}-\mathrm{Cbl}\left(5^{\prime}-\right.$ $O-\mathrm{P})-, \mathrm{CN}-\mathrm{Cbl}(b-\mathrm{OH})-, \mathrm{CN}-\mathrm{Cbl}(d-\mathrm{OH})-$ and $\mathrm{CN}-\mathrm{Cbl}(e-$ $\mathrm{OH}$ )-supplemented cells, each of the $\mathrm{Cbl}$ analogues accumulated by the cells was converted to $\mathrm{CN}-\mathrm{Cbl}$ (Table 2). The results suggest that Euglena cells have the ability to dephosphorylate $\mathrm{CN}-\mathrm{Cbl}\left(5^{\prime}-\mathrm{O}-\mathrm{P}\right)$ and amidate $\mathrm{CN}-\mathrm{Cbl}(b-\mathrm{OH}),(d-\mathrm{OH})$ and $(e-\mathrm{OH})$ to form $\mathrm{CN}-\mathrm{Cbl}$.

\section{Effect of Cbl analogues on the activities of the Euglena Cbl uptake system}

To clarify the corrinoid specificity of the Cbl uptake system of living Euglena cells, inhibition of $\mathrm{Cbl}$ uptake was studied using $\mathrm{Cbl}$ analogues (Table 3). Cbl uptake in Euglena has been reported to be a biphasic process which consists of Cbl-binding to a cell-surface receptor (energyindependent process; initial phase) and active transport (energy-dependent process; secondary phase) (Varma $e t$
Table 2. Determination of the intracellular form of corrinoids taken up by Euglena cells

Each of the analogues indicated ( $5 \mu \mathrm{g}$ per litre of medium) was added aseptically to a culture (1 litre) of Euglena cells (about $0.5 \times 10^{6}$ cells ml$\left.^{-1}\right)$ which had been grown for $5 \mathrm{~d}$ in a Cbl-limited $\left(0.22 \mathrm{ng} \mathrm{1}^{-1}\right)$ medium. The cells were cultured for a further $6 \mathrm{~d}$ and then collected by centrifuging at $2000 \mathrm{~g}$ for $10 \mathrm{~min}$ and washed three times with distilled water. The corrinoids taken up by the cells were extracted using the $\mathrm{KCN}$-boiling method, and then partially purified and analysed by HPLC as described in the text. Retention times of authentic CN-Cbl, (Bza)CN-Cba, CN-Cbl(5'$O-\mathrm{P}), \mathrm{CN}-\mathrm{Cbl}(b-\mathrm{OH}), \mathrm{CN}-\mathrm{Cbl}(d-\mathrm{OH})$ and $\mathrm{CN}-\mathrm{Cbl}(e-\mathrm{OH})$ were $12 \cdot 8,9.8,21.5,29.3,17.5$ and $23.5 \mathrm{~min}$, respectively, in water/ methanol/acetic acid $(79: 20: 1$, by vol.) as a mobile phase. The amount of intracellular $\mathrm{Cbl}$ in the $\mathrm{CN}$-Cbl-supplemented cells (control) was estimated to be $2.96 \mathrm{nmol}$ by the HPLC analysis; the amounts in the analogue-supplemented cells are expressed as a percentage of this control. The data represent mean values from three experiments. ND, Not detectable.

\begin{tabular}{lll}
\hline \hline \multirow{2}{*}{$\begin{array}{c}\text { Addition to } \\
\text { medium }\end{array}$} & \multicolumn{1}{c}{ Intracellular corrinoids $(\%$ of control) } \\
\cline { 2 - 3 } & \multicolumn{1}{c}{ Main } & \multicolumn{1}{c}{ Minor } \\
\hline $\mathrm{CN}-\mathrm{Cbl}($ control) & CN-Cbl $(100)$ & ND \\
$(\mathrm{Bza}) \mathrm{CN}-\mathrm{Cba}$ & $(\mathrm{Bza}) \mathrm{CN}-\mathrm{Cba}(89 \cdot 2)$ & $\mathrm{ND}$ \\
$\mathrm{CN}-\mathrm{Cbl}\left(5^{\prime}-\mathrm{O}-\mathrm{P}\right)$ & $\mathrm{CN}-\mathrm{Cbl}(98 \cdot 5)$ & $\mathrm{CN}-\mathrm{Cbl}\left(5^{\prime}-\mathrm{O}-\mathrm{P}\right)(<0 \cdot 5)$ \\
$\mathrm{CN}-\mathrm{Cbl}(b-\mathrm{OH})$ & $\mathrm{CN}-\mathrm{Cbl}(66 \cdot 8)$ & $\mathrm{CN}-\mathrm{Cbl}(b-\mathrm{OH})(<1 \cdot 8)$ \\
$\mathrm{CN}-\mathrm{Cbl}(d-\mathrm{OH})$ & $\mathrm{CN}-\mathrm{Cbl}(97 \cdot 8)$ & $\mathrm{CN}-\mathrm{Cbl}(d-\mathrm{OH})(<2 \cdot 2)$ \\
$\mathrm{CN}-\mathrm{Cbl}(e-\mathrm{OH})$ & $\mathrm{CN}-\mathrm{Cbl}(98 \cdot 3)$ & $\mathrm{CN}-\mathrm{Cbl}(e-\mathrm{OH})(<2 \cdot 5)$ \\
\hline \hline
\end{tabular}

al., 1961 ; Sarhan et al., 1980). [G- $\left.{ }^{3} \mathrm{H}\right] \mathrm{CN}-\mathrm{Cbl}$ uptake in the initial phase (Cbl-binding to a cell-surface receptor) was inhibited about 41,61 and $65 \%$ by addition of $100 \mathrm{nM}-\mathrm{CN}-\mathrm{Cbl}\left[2^{\prime}-O, 5^{\prime}-O-(\mathrm{Suc})_{2}\right],-\mathrm{CN}-\mathrm{Cbl}(b-\mathrm{OH})$ and 


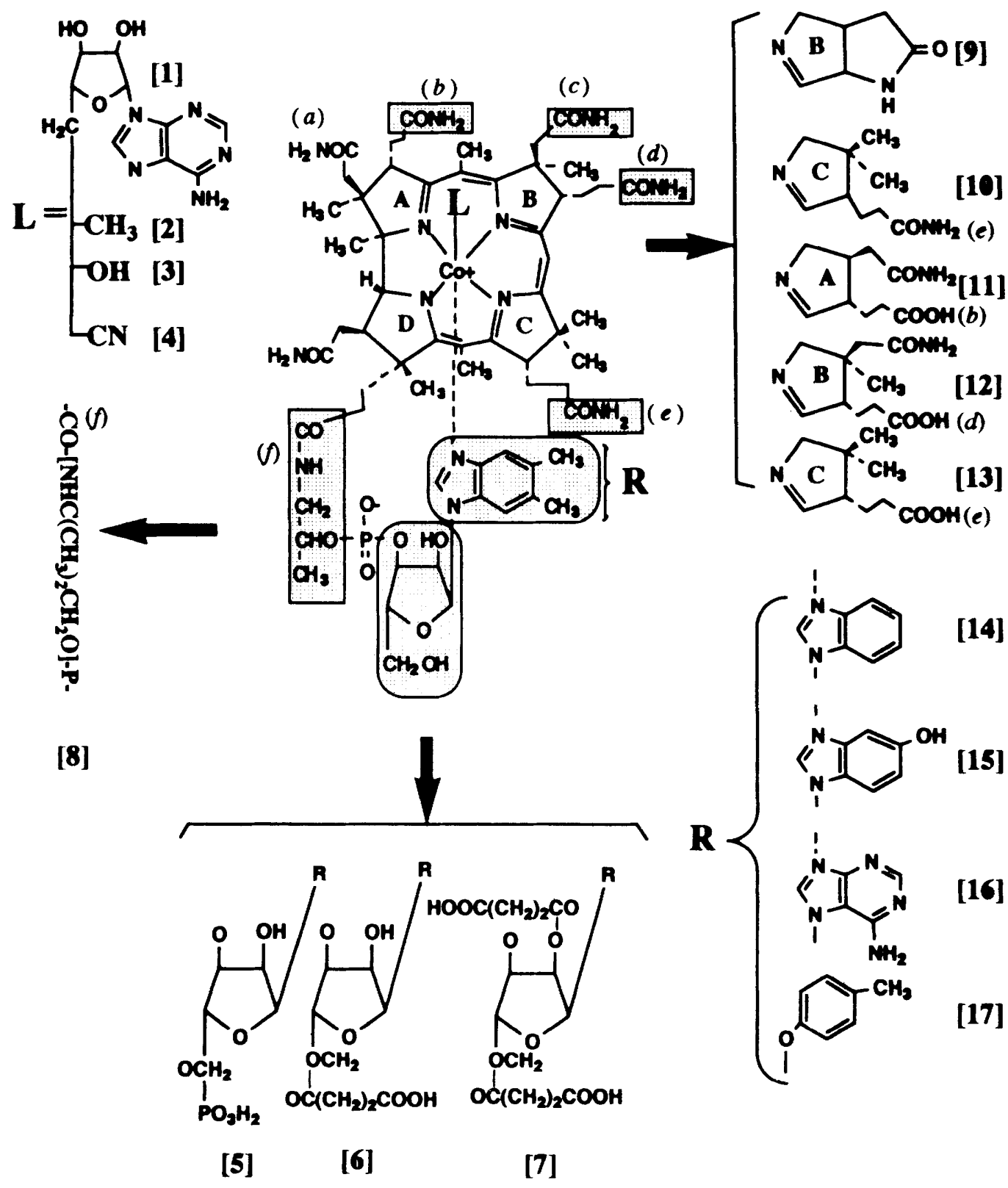

Fig. 1. Structural formulae of $\mathrm{Cbl}$ and partial structures of $\mathrm{Cbl}$ analogues. The partial structures of $\mathrm{Cbl}$ analogues show only those portions of the molecule that differ from $\mathrm{CN}-\mathrm{Cbl}$. Table 1 lists the actual compounds used for experiments. Numbers (1-17) of the structures correspond to those in Table 1.

$-(\mathrm{CN}) \mathrm{CN}-\mathrm{Cbi}$, respectively, while other $\mathrm{Cbl}$ analogues completely inhibited the uptake activity. Although $\mathrm{CN}-\mathrm{Cbl}\left[2^{\prime}-\mathrm{O}, 5^{\prime}-\mathrm{O}-(\mathrm{Suc})_{2}\right], \quad \mathrm{CN}-\mathrm{Cbl}(b-\mathrm{OH}) \quad$ and (CN)CN-Cbi did not affect $\mathrm{Cbl}$ uptake in the secondary phase (active transport), this phase of uptake was inhibited by about $47,80,83$ and $90 \%$ by ( $p$-Cre) $\mathrm{CN}$ $\mathrm{Cba}, \mathrm{CN}-\mathrm{Cbl}(d-\mathrm{OH}), \mathrm{CN}-\mathrm{Cbl}\left(5^{\prime}-O-\mathrm{P}\right)$ and $\mathrm{CN}-\mathrm{Cbl}\left(5^{\prime}-\right.$ $O$-Suc), respectively, and other analogues inhibited uptake completely. The results indicate that the cellsurface Cbl-binding reaction (initial phase) has much lower corrinoid specificity in the Cbl uptake system than does the active transport reaction (secondary phase), and that both the $\alpha$-lower axial ligand (the cobalt-coordinated nucleotide) and the (b)-propionamide side-chain of the $\mathrm{Cbl}$ molecule are essential for the uptake system in E. gracilis z. 


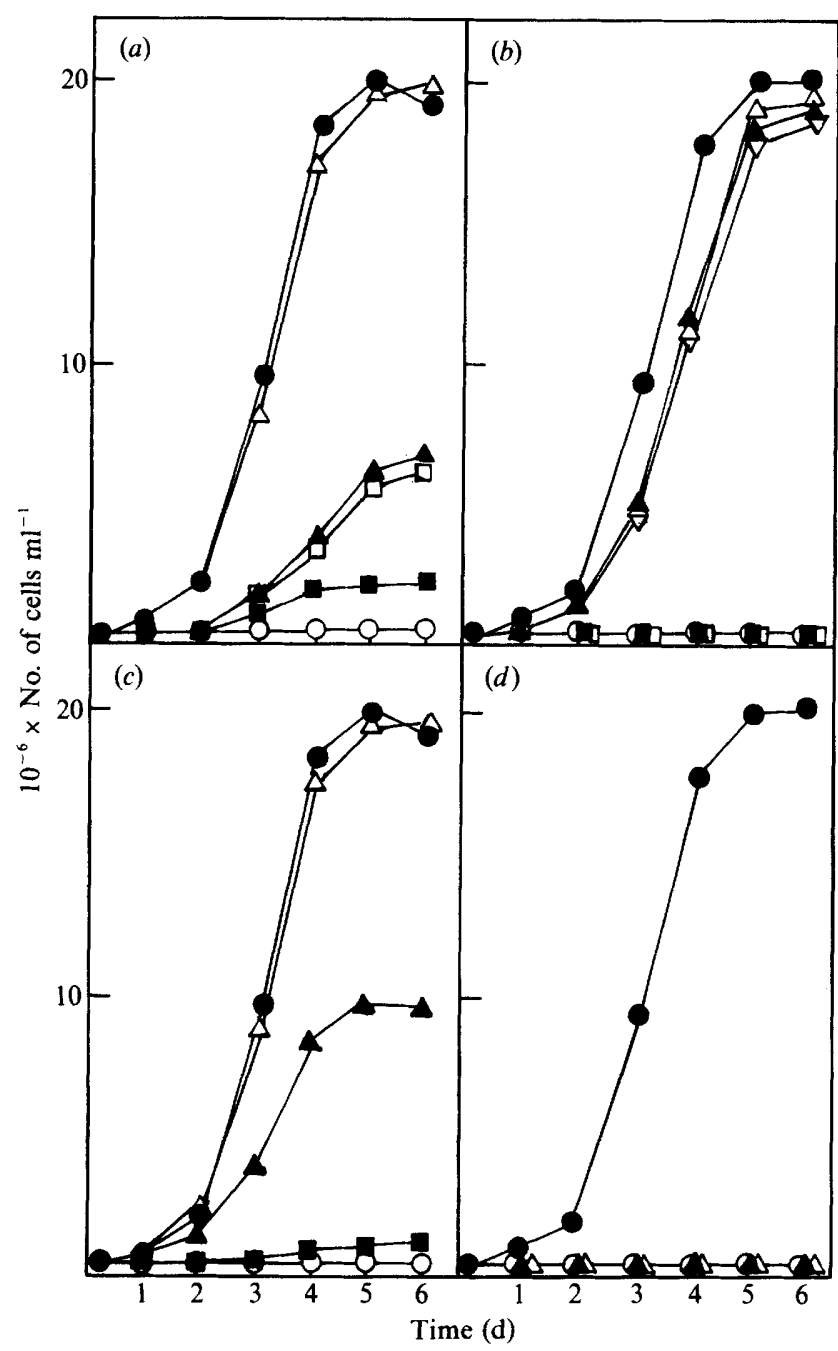

Fig. 2. Effect of $\mathrm{Cbl}$ analogues on growth of Euglena. Each of the $\mathrm{Cbl}$ analogues $(5 \mu \mathrm{g}$ per litre of medium) was added aseptically to cells which had been grown for $5 \mathrm{~d}$ in a Cbl-limited $\left(0.22 \mathrm{ng} \mathrm{l}^{-1}\right)$ medium. The cells were cultured for a further $6 \mathrm{~d}$ after addition of analogues. Cell numbers were counted in a haemocytometer every $24 \mathrm{~h}$. The data represent mean values from three experiments. (a) $\mathrm{Cbl}$ analogues with different base moieties in the $\alpha$-lower axial ligand: $\bullet, \mathrm{CN}-\mathrm{Cbl} ; \boldsymbol{\Delta}$, (5-OH-Bza)CN-Cba; $\square,(p$-Cre)CN-Cba; $\triangle$, (Bza)CN-Cba; $\square$, (Ade) $\mathrm{CN}-\mathrm{Cba} ; \mathrm{O}$, no analogue added. $(b) \mathrm{Cbl}$ analogues with modified corrin ring side-chains: $\quad \mathrm{CN}-\mathrm{Cbl} ; \Delta, \mathrm{CN}-\mathrm{Cbl}(b-\mathrm{OH}) ; \Delta$, $\mathrm{CN}-\mathrm{Cbl}(d-\mathrm{OH}) ; \nabla, \mathrm{CN}-\mathrm{Cbl}(e-\mathrm{OH}) ; \boldsymbol{\square}, \mathrm{CN}-\mathrm{Cbl}(c$-lactam $) ; \square$, $\mathrm{CN}-\mathrm{Cbl}(13-$ epi); $\mathrm{O}$, no analogue added. (c) $\mathrm{Cbl}$ analogues with a modified ribose moiety in the $\alpha$-lower axial ligand: $\bullet, \mathrm{CN}-\mathrm{Cbl} ; \triangle$, $\mathrm{CN}-\mathrm{Cbl}\left(5^{\prime}-\mathrm{O}-\mathrm{P}\right) ; \Delta, \mathrm{CN}-\mathrm{Cbl}\left(5^{\prime}-\mathrm{O}-\mathrm{Suc}\right) ; \mathbf{\square}, \mathrm{CN}-\mathrm{Cbl}\left[2^{\prime}-O, 5^{\prime}-O\right.$-(Suc) $\left.{ }_{2}\right]$; $O$, no analogue added. $(d) \mathrm{Cbl}$ analogues with a modified alkanolamine moiety and without the $\alpha$-lower axial ligand: $-\mathrm{CN}-\mathrm{Cbl} ; \Delta$, (2-AMP)CN-Cbl; $\triangle$, (CN)CN-Cbi; O, no analogue added.

\section{Discussion}

To clarify the corrinoid specificity of Euglena cell growth and the $\mathrm{Cbl}$ uptake system, a variety of $\mathrm{Cbl}$ analogues synthesized chemically or microbiologically was used (Fig. 1 and Table 1).
Table 3. Effect of $\mathrm{Cbl}$ analogues on the Euglena Cbl uptake system

Euglena cells grown for $5 \mathrm{~d}$ in a Cbl-limited (33.3 $\left.\mathrm{ng} \mathrm{1}^{-1}\right)$ medium were used for assay of $\mathrm{Cbl}$ uptake activity as described in the text. The assay mixture $(1.0 \mathrm{ml})$ contained $10 \mathrm{nM}-\left[\mathrm{G}-{ }^{3} \mathrm{H}\right] \mathrm{CN}-\mathrm{Cb}$,

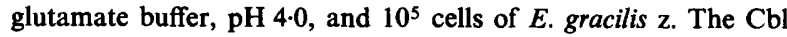
analogues were added to the mixture to a final concentration of $100 \mathrm{~nm}$. The mixture was incubated for $2 \mathrm{~h}$ at $4{ }^{\circ} \mathrm{C}$ or $27^{\circ} \mathrm{C}$ in the dark. $\mathrm{Cbl}$ uptake in the secondary phase (energy-dependent) was calculated by subtracting the radioactivity accumulated in the initial phase (energy-independent, at $4{ }^{\circ} \mathrm{C}$ ) from that at $27^{\circ} \mathrm{C}$. The data represent means \pm SD $(n=5)$.

$\mathrm{Cbl}$ uptake activity (pmol per 10-6 cells)

Initial phase

(Cbl-binding to cell- Secondary phase

Corrinoid surface receptor)

(active transport)

\begin{tabular}{|c|c|c|}
\hline None & $0.75 \pm 0.02$ & $0.76 \pm 0.03$ \\
\hline $\mathrm{CN}-\mathrm{Cbl}$ & 0 & 0 \\
\hline $\mathrm{OH}-\mathrm{Cbl}$ & 0 & 0 \\
\hline $\mathrm{CH}_{3}-\mathrm{Cbl}$ & 0 & 0 \\
\hline AdoCbl & 0 & 0 \\
\hline $\mathrm{CN}-\mathrm{Cbl}\left(5^{\prime}-O-\mathrm{P}\right)$ & 0 & $0.13 \pm 0.01$ \\
\hline $\mathrm{CN}-\mathrm{Cbl}\left(5^{\prime}-O-\mathrm{Suc}\right)$ & $0.02 \pm 0.01$ & $0.07 \pm 0.01$ \\
\hline $\mathrm{CN}-\mathrm{Cbl}\left[2^{\prime}-\mathrm{O}, 5^{\prime}-\mathrm{O}-(\mathrm{Suc})_{2}\right]$ & $0.44 \pm 0.02$ & $0.74 \pm 0.03$ \\
\hline $\mathrm{CN}-\mathrm{Cbl}(13-$ epi) & 0 & 0 \\
\hline CN-Cbl(c-lactam) & $0.01 \pm 0.01$ & $0.03 \pm 0.01$ \\
\hline $\mathrm{CN}-\mathrm{Cbl}(b-\mathrm{OH})$ & $0.29 \pm 0.01$ & $0.78 \pm 0.02$ \\
\hline $\mathrm{CN}-\mathrm{Cbl}(d-\mathrm{OH})$ & $0.03 \pm 0.01$ & $0.14 \pm 0.01$ \\
\hline $\mathrm{CN}-\mathrm{Cbl}(e-\mathrm{OH})$ & 0 & $0.03 \pm 0.01$ \\
\hline (2-AMP)CN-Cbl & 0 & 0 \\
\hline (Bza)CN-Cba & 0 & 0 \\
\hline (5-OH-Bza)CN-Cba & 0 & 0 \\
\hline (Ade)CN-Cba & 0 & 0 \\
\hline$(p-\mathrm{Cre}) \mathrm{CN}-\mathrm{Cba}$ & 0 & $0.40 \pm 0.02$ \\
\hline$(\mathrm{CN}) \mathrm{CN}-\mathrm{Cbi}$ & $0.26 \pm 0.02$ & $0.72 \pm 0.03$ \\
\hline
\end{tabular}

Regarding the base specificity in the cobalt-coordinated $\alpha$-lower axial ligand, radioactively labelled $\mathrm{CN}-\mathrm{Cbl}$ uptake inhibition experiments (Table 3) show that Euglena cells have the ability to take up (Bza)-, (5-OH-Bza)- and (Ade)-CN-Cba, as well as CN-Cbl. Euglena cells in the (Bza)CN-Cba- and CN-Cbl-supplemented cultures increased in number at identical rates through the experimental period (Fig. 2a). When total corrinoids were extracted from the (Bza)CN-Cbasupplemented cells and analysed by HPLC, most of the corrinoids extracted were recovered in the (Bza)CN-Cba fraction (Table 2), of which the synthetic coenzyme form, (Bza)AdoCba, has been reported to be active in AdoCbl-dependent methylmalonyl-CoA mutases (Abeles \& Lee, 1961; Lengyel et al., 1960). This strongly suggests that the (Bza)CN-Cba taken up by Euglena cells was converted to the coenzyme forms that function as the prosthetic groups of the three Cbl-dependent enzymes known in $E$. gracilis z (methionine synthase, methylmalonyl-CoA mutase and ribonucleotide reductase). The (5-OH-Bza)- and (Ade)-CN-Cba-supplemented cultures 
gave about $30 \%$ of the cell growth increase seen in the $\mathrm{CN}$-Cbl-supplemented cultures (Fig. 2a). This lower increase in Cba-supplemented cultures could be due to difficulty in the formation of the Cbl-dependent enzyme-Cba complex because (Ade)AdoCba has been reported to have much lower affinity for some AdoCbldependent enzymes than AdoCbl itself (Lengyel et al., 1960; Kung \& Stadmann, 1971). The ( $p$-Cre)CN-Cbasupplemented Euglena cultures grew at only about $10 \%$ of the rate of $\mathrm{CN}-\mathrm{Cbl}$-supplemented cultures. This seems to be because ( $p$-Cre)CN-Cba has a considerably lower affinity for the Euglena uptake system (Table 3). (CN)CN-Cbi did not affect the activities of the $\mathrm{Cbl}$ uptake system (Table 3) nor did it support an increase in growth of (CN)CN-Cbi-supplemented cultures (Fig. $2 d$ ). The results indicate that Euglena cells are not able to take up 'incomplete' corrinoids like (CN)CN-Cbi, because a suitable $\alpha$-lower axial ligand (presence of the cobalt-coordinated nucleotide) of the $\mathrm{Cbl}$ molecule is essential for the Euglena $\mathrm{Cbl}$ uptake system.

Radioactive $\mathrm{CN}-\mathrm{Cbl}$ uptake inhibition experiments with $\mathrm{OH}-\mathrm{Cbl}, \mathrm{CH}_{3}-\mathrm{Cbl}$ or AdoCbl (Table 3) indicate that the $\beta$-upper axial ligand of $\mathrm{Cbl}$ molecule is not essential for the Euglena uptake system.

(2-AMP)CN-Cbl, which contains 2-amino-2-methylpropanol instead of 1-amino-2-methylpropanol as an alkanolamine group, has been reported to inhibit cell growth of $E$. coli and $O$. malhamensis (Friedrich et al., 1964). This analogue had no effect on Euglena cell growth (Fig. 1d). The results in Table 3 suggest that (2-AMP)CN-Cbl can be taken up by Euglena cells. Inhibition of the Cbl-dependent enzymes by the analogue, which has been reported to completely inhibit activity of an AdoCbl-dependent diol dehydrase (Kung \& Stadmann, 1971), may explain why this analogue does not support a growth increase. The present results were different from our previous studies, which suggested that (2-AMP)CN-Cbl did not affect the activity of some Euglena Cbl-binding proteins (Watanabe et al., 1987a, b; $1988 a, b)$. We are, however, unable to explain why such differences in the analogue-binding behaviour occurred.

Although it has been reported that $\mathrm{CN}-\mathrm{Cbl}\left(5^{\prime}-O-\mathrm{P}\right)$, $\left(5^{\prime}-O\right.$-Suc) and $\left[2^{\prime}-O, 5^{\prime}-O-(\mathrm{Suc})_{2}\right]$ do not inhibit labelled $\mathrm{CN}-\mathrm{Cbl}$ uptake by $E$. coli (White et al., 1973; Toraya $e t$ $a l ., 1975 a$ ), the results in Table 3 indicate that Euglena cells have the ability to take up $\mathrm{CN}-\mathrm{Cbl}\left(5^{\prime}-O-\mathrm{P}\right)$ and $\left(5^{\prime}-O-\mathrm{Suc}\right)$, but not $\left.\left[2^{\prime}-O, 5^{\prime}-O \text {-(Suc }\right)_{2}\right]$, which had no effect on Euglena cell growth. The increase in growth of $\mathrm{CN}-\mathrm{Cbl}\left(5^{\prime}-\mathrm{O}-\mathrm{P}\right)$-supplemented cultures was the same as that of $\mathrm{CN}$-Cbl-supplemented cultures (control), but $\mathrm{CN}-\mathrm{Cbl}\left(5^{\prime}-O\right.$-Suc)-supplemented cultures grew at only about $50 \%$ of the rate of the control (Fig. $2 c$ ). It became clear that the $\mathrm{CN}-\mathrm{Cbl}\left(5^{\prime}-\mathrm{O}-\mathrm{P}\right)$ taken up by the cells was dephosporylated to $\mathrm{CN}-\mathrm{Cbl}$ (Table 2). E. gracilis $\mathrm{z}$ has been reported to contain a non-specific phosphatase which is involved in vitamin $B_{1}$ (in particular thiamin pyrophosphate) uptake and is located in the cell surface region (Shigeoka et al., 1987; Nakano et al., 1987). The non-specific phosphatase may function in the dephosphorylation of $\mathrm{CN}-\mathrm{Cbl}\left(5^{\prime}-O-\mathrm{P}\right)$ as well as thiamin pyrophosphate prior to uptake of the compounds. An enzymic system for dephosphorylation of $\mathrm{CN}-\mathrm{Cbl}\left(5^{\prime}\right.$ $O$-P) has been studied in some bacteria (Schneider \& Friedmann, 1972). The lower growth rate of the $\mathrm{CN}-\mathrm{Cbl}\left(5^{\prime}-\mathrm{O}\right.$-Suc)-supplemented cultures in comparison with $\mathrm{CN}-\mathrm{Cbl}\left(5^{\prime}-\mathrm{O}-\mathrm{P}\right)$-supplemented cultures may be because the conversion of $\mathrm{CN}-\mathrm{Cbl}\left(5^{\prime}-\mathrm{O}-\mathrm{Suc}\right)$ to $\mathrm{CN}-\mathrm{Cbl}$ is a rate-limiting step for cell growth.

It has been reported that both $\mathrm{CN}-\mathrm{Cbl}(13-e p i)$ and -(c-lactam) inhibit E. coli growth (Bonnett et al., 1957; $1971 a$ ) and that AdoCbl(13-epi) also is inactive in some AdoCbl-dependent enzymes (Renz, 1971; Toraya et al., $1975 b$ ). The results in Table 3 indicate that Euglena cells have the ability to take up both $\mathrm{CN}-\mathrm{Cbl}(13$-epi) and -(c-lactam), but neither analogue affected cell growth (Fig. 2b). The results in Table 3 also show that Euglena cells are capable of taking up $\mathrm{CN}-\mathrm{Cbl}(d-\mathrm{OH})$ and $(e-\mathrm{OH})$, but not $(b-\mathrm{OH})$, indicating that the $(b)$-propionamide side chain of the $\mathrm{Cbl}$ molecule is essential for the Euglena $\mathrm{Cbl}$ uptake system. $\mathrm{CN}-\mathrm{Cbl}(b-\mathrm{OH})$-supplemented Euglena cultures, however, grew as effectively as $\mathrm{CN}-\mathrm{Cbl}(d-\mathrm{OH})$ - or $\mathrm{CN}-\mathrm{Cbl}(e-\mathrm{OH})$-supplemented cultures. Each of the $\mathrm{CN}-\mathrm{Cbl}$ acid derivatives accumulated by the cells was converted to $\mathrm{CN}-\mathrm{Cbl}$ (Table 2). These results suggest that the enzyme involved in the conversion of each of the acid derivatives to $\mathrm{CN}-\mathrm{Cbl}(\mathrm{CN}-\mathrm{Cbl}$ monocarboxylic acid amide synthase) occurs in $E$. gracilis $\mathrm{z}$, probably in the cell surface region. A Cblproducing bacterium, Pseudomonas denitrificans, has been reported to contain the enzyme cobyrinic acid $a, c$-diamide synthase, which is involved in Cbl biosynthesis (Debussche et al., 1990).

The results presented here also provide useful information for the microbiological assay of $\mathrm{Cbl}$, because E. gracilis $\mathrm{z}$ has been widely used for the bioassay of $\mathrm{Cbl}$ (Ross, 1952).

\section{References}

Abeles, R. H. \& LeE, H. A., JR (1961). An intramolecular oxidationreduction requiring a cobamide coenzyme. Journal of Biological Chemistry 236, 2347-2535.

Anton, D. L., Hogenkamp, H. P. C., Walker, T. E. \& Matwiyoff, N. A. (1980). Carbon-13-nuclear magnetic resonance studies of the monocarboxylic acids of cyanocobalamin : assignments of the $b-, d$, and $e$-monocarboxylic acids. Journal of the American Chemical Society 102, 2215-2219.

Bonnett, R., Cannon, J. R., Clark, V. M., Johnson, A. W., Parker, L. F. J., SMITH, E. L. \& TODD, A. (1957). Chemistry of the vitamin $B_{12}$ group. V The structure of the chromophoric grouping. Journal of the American Chemical Society 1158-1168. 
BonNett, R., Godfrey, J. M., MATH, V. B., Edmond, E., Evans, H. \& HODDER, O. J. R. (1971a). Neovitamin $B_{12}$ identified. Nature, London 229, 473-476.

BonnetT, R., Godfrey, J. M. \& Math, V. B. (1971b). Cyano-13epicobalamin (neovitamin $B_{12}$ ) and its relatives. Journal of the Chemical Society 3736-3747.

BRADBEER, C. (1971). Transport of vitamin $B_{12}$ in Ochromonas malhamensis. Archives of Biochemistry and Biophysics 144, 184-197.

BRADBEer, C. \& WoOdrow, M. L. (1976). Transport of vitamin $B_{12}$ in Escherichia coli: energy dependence. Journal of Bacteriology 128 , 99-104.

Debussche, L., Thibaut, D., Cameron, B., Crouzet, J. \& Blance, F. (1990). Purification and characterization of cobyrinic acid $a, c$-diamide synthase from Pseudomonas denitrificans. Journal of Bacteriology 172, 6239-6244.

DiGirolamo, P. M. \& Bradbeer, C. (1971). Transport of vitamin $B_{12}$ in Escherichia coli. Journal of Bacteriology 106, 745-750.

FriedmanN, H. C. (1971). Synthesis of vitamin $B_{12} 5^{\prime}$-phosphate. Methods in Enzymology 18C, 54-57.

FrIEDRICH, W. (1964). Vitamin B $_{12}$. In Biochemisches Taschenbuch, p. 708. Edited by H. M. Rauen. Berlin: Springer-Verlag.

Friedrich, W., HeInRICH, H. C., KonigK, E. \& SchUlze, P. (1964). Chemical synthesis and some biological properties of the coenzyme forms of an alkanolamine-type $\mathrm{B}_{12}$-antivitamin. Annals of the New York Academy of Sciences 112, 601-614.

Isegawa, Y., Nakano, Y. \& KitAoka, S. (1984). Conversion and distribution of cobalamin in Euglena gracilis z, with special reference to its location and probable function within chloroplasts. Plant Physiology 76, 814-818.

Koren, L. E. \& Hutner, S. H. (1967). High-yield media for photosynthesizing Euglena gracilis. Journal of Protozoology 14 (Suppl.), 17.

Kung, H. F. \& Stadmann, T. C. (1971). Nicotinic acid metabolism. IV. Purification and properties of $\alpha$-methyleneglutarate mutase $\left(B_{12^{-}}\right.$ dependent) and methylitaconate isometase. Journal of Biological Chemistry 246, 3378-3388.

Lengyel, P., MAZumder, R. \& OCHOA, S. (1960). Mammalian methylmalonyl isomerase and vitamin $B_{12}$ coenzymes. Proceedings of the National Academy of Sciences of the United States of America 46, 1312-1318.

NaKano, Y., Urade, Y., URADE, R. \& Kitaoka, S. (1987). Isolation, purification, and characterization of the pellicle of Euglena gracilis $\mathbf{z}$. Journal of Biochemistry 102, 1053-1063.

RENZ, P. (1971). Some intermediates in the biosynthesis of vitamin $\mathrm{B}_{12}$. Methods in Enzymology 18C, 82-92.

Ross, G. I. M. (1952). Vitamin $B_{12}$ assay in body fluids using Euglena gracilis. Journal of Clinical Pathology 5, 250-256.

Sarhan, F., Houde, M. \& Cheneval, J. P. (1980). The role of vitamin $\mathrm{B}_{12}$ binding in the uptake of the vitamin by Euglena gracilis. Journal of Protozoology 27, 235-238.

SCHNEIDER, Z. \& FriedmanN, H. C. (1972). Studies on the enzymatic dephosporylation of vitamin $B_{12} 5^{\prime}$-phosphate. Archives of Biochemistry and Biophysics 152, 488-492.

Shigeoka, S., Onishi, T., Nakano, Y. \& Kitaoka, S. (1987). Requirement for vitamin $B_{1}$ for growth of Euglena gracilis. Journal of General Microbiology 133, 25-30.

StUPPERICH, E. \& KRAUTler, B. (1988). Pseudovitamin B $_{12}$ or 5-hydroxybenzimidazolyl-cobamide are the corrinoids found in methanogenic bacteria. Archives of Microbiology 149, 268-271.
StupPerich, E., Steiner, I. \& RuhlemanN, M. (1986). Isolation and analysis of bacterial cobamides by high-performance liquid chromatography. Analytical Biochemistry 155, 365-370.

StupPerich, E., EISINGER, H. J. \& KraUtler, B. (1988). Diversity of corrinoids in acetogenic bacteria, $p$-cresolyl cobamide from Sporomusa ovata, 5-methoxy-6-methylbenzimidazolyl cobamide from Clostridium woodii. European Journal of Biochemistry 172, 459464.

StUPPERICH, E., EINSINGer, H. J. \& SchURR, S. (1990). Corrinoids in anaerobic bacteria. FEMS Microbiology Reviews 87, 355-360.

TKachuck, R. D., Grant, M. E. \& Hogenkamp; H. P. C. (1974). Synthesis and properties of adenosyl- and methylepicobalamin. Biochemistry 13, 2643-2654.

Toraya, T., Krodel, E., Mildvan, A. S. \& Abeles, R. H. (1979). Role of peripheral side chains of vitamin $B_{12}$ coenzymes in the reaction catalyzed by diol dehydrase. Biochemistry 18, 417-426.

Toraya, T., Ohashi, K., Ueno, H. \& Fukui, S. (1975a). Preparation, properties and biological activities of succinyl derivatives of vitamin $B_{12}$. Bioinorganic Chemistry 4, 245-255.

Toraya, T., Shirakashi, T., Fukui, S. \& Hogenkamp, H. P. C. $(1975 b)$. Coenzyme action of adenosyl-13-epicobalamin in the diol dehydrase system. Biochemistry 14, 3949-3952.

Yamada, R. H. \& HogenKamp, H. P. C. (1972). The synthesis of a 5 -deoxyadenosylcobalamin-agarose absorbent and its utility in the purification of ribonucleotide reductase. Journal of Biological Chemistry 247, 6266-6270.

Varma, T. N. S., Abraham, A. \& Hansen, I. A. (1961). Accumulation of ${ }^{58}$ Co vitamin $\mathrm{B}_{12}$ by Euglena gracilis. Journal of Protozoology 8 , 212-216.

Watanabe, F. \& Nakano, Y. (1991). Comparative biochemistry of vitamin $B_{12}$ (cobalamin) metabolism: biochemical diversity in the systems for intracellular cobalamin transfer and synthesis of the coenzymes. International Journal of Biochemistry 23, 1354-1359.

Watanabe, F., NAKano, Y.\& KITAOKa, S. (1987a). Isolation and some properties of soluble and membrane-bound cobalamin binding proteins of Euglena mitochondria. Archives of Microbiology 149, 30-35.

Watanabe, F., Nakano, Y. \& Kitaoka, S. (1987b). Purification and some properties of cytosolic cobalamin-binding protein in Euglena gracilis. Biochemical Journal 247, 679-685.

Watanabe, F., Ito, T., Tabuchi, T., Nakano, Y. \& Kitaoka, S. $(1988 a)$. Isolation of pellicular cobalamin-binding proteins of the cobalamin uptake system of Euglena gracilis. Journal of General Microbiology 134, 67-74

Watanabe, F., Nakano, Y. \& Kitaoka, S. (1988b). Purification, some properties and possible physiological role of an extracellular cobalamin-binding protein from Euglena gracilis. Journal of General Microbiology 134, 1385-1389.

Watanabe, F., Nakano, Y., Tamura, Y. \& Yamanaka, H. (1991) Vitamin $B_{12}$ metabolism in a photosynthesizing green alga, Chlamydomonas reinhardtii. Biochimica et Biophysica Acta 1075, 36-41.

White, J. C., Digirolamo, P. M., Fu, M. L., Preston, Y. A. \& BRADBEER, C. (1973). Transport of vitamin $B_{12}$ in Escherichia coli: location and properties of the initial $\mathrm{B}_{12}$-binding site. Journal of Biological Chemistry 248, 3978-3986.

Wolken, J. J. (1967). Euglena, p. 24. New York: Meredith Publishing Company. 